\title{
Diabetogenic action of alloxan-like compounds: cytotoxic effects of 5-hydroxy-pseudouric acid and dehydrouramil hydrate hydrochloride on rat pancreatic $\beta$ cells
}

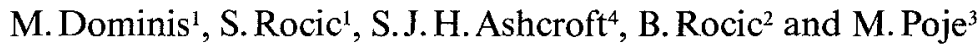 \\ 'Department of Pathology, Clinical Hospital 'Ozren Novosel', Medical Faculty, ${ }^{2}$ Institute for Diabetes 'Vuk Vrhovac', Medical Faculty, \\ and ${ }^{3}$ Laboratory of Organic Chemistry, Faculty of Science, University of Zagreb, Yugoslavia; \\ ${ }^{4}$ Nuffield Department of Clinical Biochemistry, John Radcliffe Hospital, Oxford, UK
}

\begin{abstract}
Summary. The effects on islet morphology and blood glucose concentration of intravenous administration of alloxan to rats have been compared with those of two new diabetogenic agents, 5-hydroxy-pseudouric acid (5-HPUA) and dehydrouramil hydrate hydrochloride (DHU). Administration of alloxan $(0.35 \mathrm{mmol} / \mathrm{kg})$ caused a classical triphasic change in blood glucose characterised by initial hyperglycaemia, subsequent hypoglycaemia and a delayed persistent hyperglycaemia. In contrast, 5-HPUA and DHU elicited persistent hyperglycaemia as early as $\mathbf{3 0} \mathrm{min}$ after administration. Morphological evidence for degranulation, pyknosis, necrosis and widening of pericapillary spaces was obtained with all three agents. However, both 5-HPUA and DHU elicit considerably more rapid and extensive changes than alloxan, with evidence for extensive pyknosis occurring as early as $15 \mathrm{~min}$ after ad-
\end{abstract}

ministration of DHU and 5-HPUA compared with $24 \mathrm{~h}$ for alloxan. The more marked potency of DHU and 5-HPUA may be at least partially attributable to the greater stability of these agents compared with alloxan, since solutions of DHU or 5-HPUA kept for 15 min prior to administration retained full diabetogenic activity, whereas similar treatment of alloxan solution completely abolished its diabetogenic activity. Since both 5-HPUA and DHU are potential metabolites of uric acid, their marked diabetogenic potency raises the possibility of a role for uric acid metabolites in the pathogenesis of diabetes mellitus.

Key words: Alloxan, dehydrouramil, 5-hydroxy-pseudouric acid, diabetes.
The structural elucidation of intermediates in the oxidative breakdown of uric acid [1-3] have helped to unravel the chemistry and biological effects of alloxan-like compounds derived from uric acid. Recently we reported the production of permanent diabetes in rats by the intravenous administration of either 5-hydroxy-5-ureido-2,4,6(1H,3H,5H)-pyrimidinetrione (5-hydroxypseudouric acid, 5-HPUA) or 5-amino-5-hydroxy-2,4,6 $(1 \mathrm{H}, 3 \mathrm{H}, 5 \mathrm{H})$-pyrimidinetrione hydrochloride (dehydrouramil hydrate hydrochloride, DHU) $[4,5]$. These new compounds were among the most active diabetogenic agents: in comparison with alloxan, there is a twofold difference in $\mathrm{ED}_{50}$ values; moreover the $\mathrm{ED}_{50}$ of both alloxan-like compounds corresponded to a dose of alloxan which does not in itself cause diabetes. Studies of DHU on isolated rat islets of Langerhans in vitro have shown a spectrum of acute effects on the $\beta$ cell similar in many respects to that of alloxan [6]. Substantial inhibition of glucose-stimulated insulin release was achieved at a concentration $(0.5 \mathrm{mmol} / \mathrm{l})$ of DHU that did not affect islet glucose oxidation or ATP content. Thus a derangement of energy metabolism is not the primary cause for impairment of insulin release. These findings may serve to renew a plausible hypothesis for the aetiology of diabetes mellitus, that a substance biogenetically related to uric acid may have an alloxan-like action on the islet $\beta$ cells [7]. Since the mechanism of production of alloxan diabetes is still obscure, a careful study of new compounds may also be helpful in elucidating this mechanism.

The present study presents a detailed comparison of the time-course of changes in islet morphology and blood glucose in response to alloxan, 5-HPUA and DHU.

\section{Materials and methods}

\section{Reagents}

All reagents were of analytical grade. 5-HPUA [2] and DHU [5] were prepared according to published procedures.

\section{Animals}

All experiments were performed with male Lewis rats, weighing $200 \pm 20 \mathrm{~g}$. In all, 120 animals were reared on standard laboratory 
Table 1. Blood-glucose response to equimolar doses of alloxan and alloxan-like compounds

\begin{tabular}{|c|c|c|c|c|c|c|c|c|c|}
\hline \multirow{2}{*}{$\begin{array}{l}\text { Compound } \\
(0.35 \mathrm{mmol} / \mathrm{kg})\end{array}$} & \multicolumn{9}{|c|}{ Blood glucose $(\mathrm{mmol} / \mathrm{l})$ at time: } \\
\hline & Initial & $15 \mathrm{~min}$ & $30 \mathrm{~min}$ & $1.5 \mathrm{~h}$ & $6 \mathrm{~h}$ & $8 \mathrm{~h}$ & $10 \mathrm{~h}$ & $12 \mathrm{~h}$ & $24 \mathrm{~h}$ \\
\hline Control & $\begin{array}{l}3.61 \pm 0.28 \\
(10)\end{array}$ & $\begin{array}{l}4.28 \pm 0.50 \\
(10)\end{array}$ & $\begin{array}{l}3.89 \pm 0.39 \\
(10)\end{array}$ & $\begin{array}{l}3.67 \pm 0.56^{\mathrm{a}} \\
(10)\end{array}$ & $\begin{array}{l}3.89 \pm 0.56 \\
(6)\end{array}$ & $\begin{array}{l}4.17 \pm 0.61 \\
(6)\end{array}$ & $\begin{array}{l}3.89 \pm 0.56 \\
(6)\end{array}$ & $\begin{array}{l}4.22 \pm 0.56 \\
(6)\end{array}$ & $\begin{array}{l}4.33 \pm 0.72^{\mathrm{a}} \\
(6)\end{array}$ \\
\hline Alloxan & $\begin{array}{l}3.66 \pm 0.28 \\
(30)\end{array}$ & $\begin{array}{l}4.06 \pm 0.44^{a} \\
(30)\end{array}$ & $\begin{array}{l}3.78 \pm 0.56 \\
(26)\end{array}$ & $\begin{array}{l}9.56 \pm 2.44^{a . c} \\
(26)\end{array}$ & $\begin{array}{l}5.06 \pm 0.83 \\
(17)\end{array}$ & $\begin{array}{l}3.33 \pm 1.56 \\
(17)\end{array}$ & $\begin{array}{l}1.56 \pm 0.78^{c} \\
(17)\end{array}$ & $\begin{array}{l}2.11 \pm 0.67^{\mathrm{a}, \mathrm{c}} \\
(17)\end{array}$ & $\begin{array}{l}16.94 \pm 2.83^{\mathrm{a}, \mathrm{c}} \\
(12)\end{array}$ \\
\hline DHU & $\begin{array}{l}3.78 \pm 0.22 \\
(30)\end{array}$ & $\begin{array}{l}4.33 \pm 0.50^{\mathrm{a}} \\
(30)\end{array}$ & $\begin{array}{l}12.00 \pm 2.22^{\mathrm{c}} \\
(26)\end{array}$ & $\begin{array}{l}12.17 \pm 2.06^{\mathrm{a} c} \mathrm{c} \\
(26)\end{array}$ & $\begin{array}{l}10.56 \pm 2.61^{c} \\
(17)\end{array}$ & $\begin{array}{l}9.72 \pm 1.28^{c} \\
(17)\end{array}$ & $\begin{array}{l}14.94 \pm 4.83^{\mathrm{c}} \\
(17)\end{array}$ & $\begin{array}{l}17.11 \pm 7.00^{\mathrm{a}} \\
(17)\end{array}$ & $\begin{array}{l}25.83 \pm 7.94^{\mathrm{a}, \mathrm{c}} \\
(13)\end{array}$ \\
\hline Alloxan ${ }^{b}$ & $\begin{array}{l}2.44 \pm 0.39 \\
(10)\end{array}$ & $\begin{array}{l}2.67 \pm 0.39 \\
(10)\end{array}$ & $\begin{array}{l}3.06 \pm 0.50 \\
(10)\end{array}$ & $\begin{array}{l}8.67 \pm 1.78^{c} \\
(10)\end{array}$ & $\begin{array}{l}4.89 \pm 0.78^{c} \\
(10)\end{array}$ & $\begin{array}{l}3.11 \pm 0.61 \\
(10)\end{array}$ & $\begin{array}{l}1.28 \pm 0.56 \\
(10)\end{array}$ & $\begin{array}{l}1.61 \pm 0.50 \\
(9)\end{array}$ & $\begin{array}{l}16.06 \pm 3.67^{c} \\
\text { (9) }\end{array}$ \\
\hline 5-HPUA ${ }^{b}$ & $\begin{array}{l}1.89 \pm 0.22 \\
(10)\end{array}$ & $\begin{array}{l}2.22 \pm 0.22 \\
(10)\end{array}$ & $\begin{array}{l}2.44 \pm 0.33 \\
(10)\end{array}$ & $\begin{array}{l}2.67 \pm 0.56^{\mathrm{c}} \\
(10)\end{array}$ & $\begin{array}{l}16.00 \pm 2.00^{c} \\
(10)\end{array}$ & $\begin{array}{l}16.00 \pm 3.39^{c} \\
(10)\end{array}$ & $\begin{array}{l}13.61 \pm 5.33^{c} \\
(10)\end{array}$ & $\begin{array}{l}14.56 \pm 5.78 \\
(10)\end{array}$ & $\begin{array}{l}21.56 \pm 5.89^{c} \\
(10)\end{array}$ \\
\hline
\end{tabular}

Results are given as mean \pm SEM for the number of animals in parentheses.

a Samples for histological examinations.

b Animals were starved for $24 \mathrm{~h}$ before administration of compounds.

c $p<0.05$ significantly different from initial value
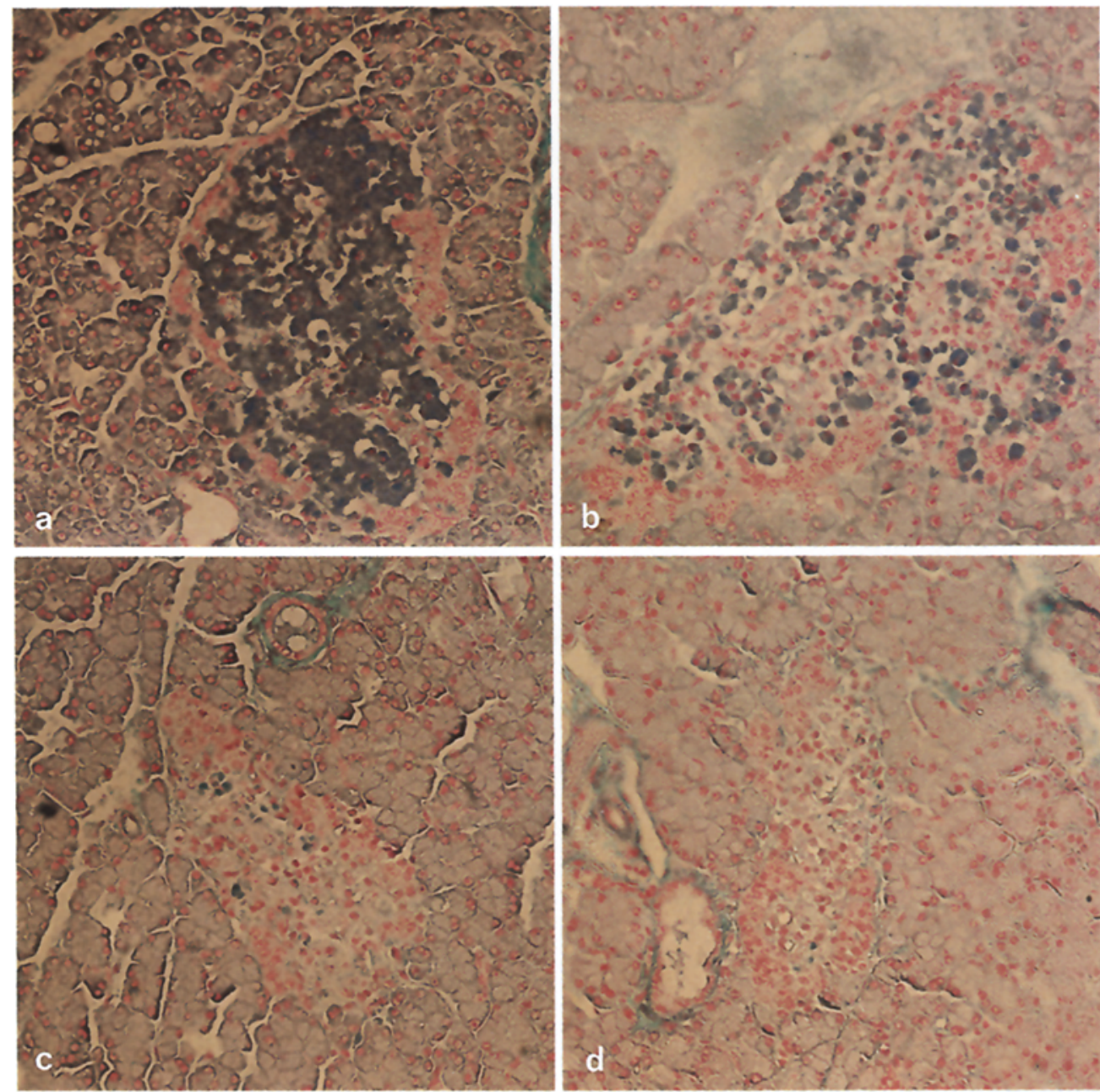

Fig. 1 a-d. Histological changes in rat pancreatic islets after administration of alloxan, 5-HPUA and DHU. a Normal rat islet. The $\beta$ cells (blue) constitute the chief component; the $\alpha$ cells (red) are situated mostly in the periphery of the islet. b-d Islets of Langerhans $12 \mathrm{~h}$ after an intravenous injection of $0.35 \mathrm{mmol} / \mathrm{kg}$ of $\mathbf{b}$ Alloxan. The $\beta$ cells are disintegrated; a few $\beta$ cells are necrotic and already collapsed, whereas the $\alpha$ cells are unchanged. c 5-HPUA.

Homogenous necrotic mass with some nuclear debris is formed at the centre. No marked change in the periphery. d $D H U$. The islet is remarkably dwarfed, consisting almost entirely of $\alpha$ cells; the remaining necrotic mass is seen at the centre. Kikui's differential staining was employed $(\times 120)$ 
Table 2. Effects of equimolar doses of alloxan and alloxan-like compounds on islet $\beta$ cells

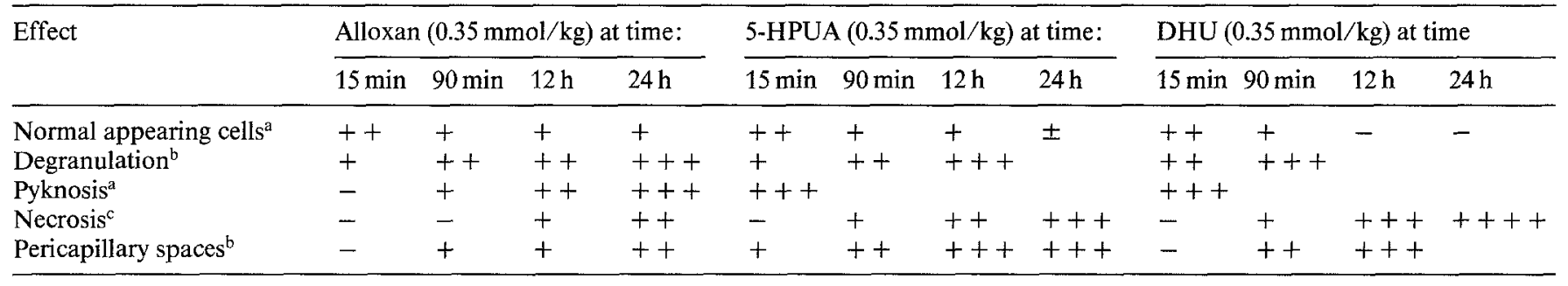

a A few + , about half ++ , almost all cells +++ .

b Slight + , moderate ++ , extensive +++ .

c eosinophil clumping or cloudily swelling + , disrupture of cells ++ , extensive +++ , complete necrosis ++++

chow and were starved overnight or $24 \mathrm{~h}$ before injection. Freshly prepared $2 \%$ saline solutions of drugs were given intravenously into a tail vein.

\section{Studies on blood glucose concentration and islet morphology}

The effects of equimolar doses $(0.35 \mathrm{mmol} / \mathrm{kg})$ of alloxan, 5 -HPUA, and DHU on the blood glucose concentrations and the islet morphology were compared in rats. At times indicated in the experiment, blood samples were taken from a tail vein. Blood glucose concentrations were measured in duplicate by the glucose oxidase method [8]. For the studies of islet morphology, animals were sacrified and the pancreatic glands were excised and fixed in Bouin's fluid for $2 \mathrm{~h}$. After fixation the specimens were washed in $70 \%$ alcohol and embedded in paraffin. Pancreatic sections were stained with Victoria Blue B and fuchsine acid according to Kikui's differential staining method for $\alpha$ and $\beta$ cells [9].

Fifteen islets chosen at random from each experimental group were analysed with respect to the normal appearance of the $\beta$ cells, their degree of degranulation, pyknosis, necrosis, and the degree of widening of pericapillary spaces. Liver and kidney specimens were also taken and embedded in paraffin for the routine haematoxylineosin staining procedure.

\section{Statistical analysis}

Data are given as mean \pm SEM and the significance of the observed differences was assessed by two-tailed Student's t-test.

\section{Results}

\section{Blood glucose concentration and islet morphology}

The fluctuations of blood glucose levels after administration of diabetogenic doses $(0.35 \mathrm{mmol} / \mathrm{kg})$ of alloxan, 5-HPUA, and DHU are shown in Table 1. A typical triphasic blood glucose response was observed in alloxan-treated animals, whereas in rats treated with either 5-HPUA or DHU the early hyperglycaemic and hypoglycaemic phases were completely absent; persistent hyperglycaemia was established $30 \mathrm{~min}$ after administration of the drugs in animals fasted overnight. Starvation for $24 \mathrm{~h}$ before administration of the drug delayed the blood glucose response to DHU or 5-HPUA but not to alloxan. The morphology of islets of Langerhans $12 \mathrm{~h}$ after administration of saline alone or $0.35 \mathrm{mmol} / \mathrm{kg}$ of test substance is shown in Figure 1. Alloxan was $\beta$-cyto- toxic in rats (Fig. 1 b) but the lesions were in no case as extensive as those after an equimolar dose $(0.35 \mathrm{mmol} /$ $\mathrm{kg}$ ) of either 5-HPUA (Fig. $1 \mathrm{c}$ ) or the most active DHU (Fig. $1 \mathrm{~d}$ ). Although $\beta$ cells of normal appearance could be found even $24 \mathrm{~h}$ after administration of alloxan, no $\beta$ cells were found at this time with 5-HPUA. An equimolar dose of DHU resulted in complete disappearance of $\beta$ cells as early as $12 \mathrm{~h}$ after administration. The histological changes in the islets as a consequence of $\mathrm{DHU}$ injection are characteristic; definite pyknosis of nuclei and degranulation are noted in the $\beta$ cells about $15 \mathrm{~min}$ after administration. After $90 \mathrm{~min}, \beta$ cells become disintegrated and form an extensive necrotic mass in the islets. In the ensuing hours the necrotic mass is absorbed and removed by the end of $12 \mathrm{~h}$. The islet eventually consists only of $\alpha$ cells, which show little regressive changes. A comparison between alloxan-induced changes in the islets of Langerhans and those induced by new alloxan-like compounds are shown in Table 2 . In all experiments $\alpha$ cells remained unchanged, and no changes were found in the liver and kidney tissues, as assessed by the routine haematoxylin-eosin procedure. In comparing 5-HPUA and DHU with alloxan, it can be seen that there is a marked difference in the $\beta$-cytotoxic activity, consistent with their approximately 50\% lower $\mathrm{ED}_{50}[4,5]$. To determine the effect of the decomposition rates of alloxan, 5-HPUA, and DHU on their diabetogenic activity, experimental groups of rats were treated with an equimolar dose $(0.35 \mathrm{mmol} / \mathrm{kg})$ of each compound that had been allowed to decompose in the solution for $15 \mathrm{~min}$. This procedure produced no significant alteration in diabetogenic activity of 5-HPUA and DHU, but abolished the diabetogenic effect of alloxan solution.

\section{Discussion}

The data presented here confirm previous reports of a high diabetogenic potency of 5-HPUA [4] and DHU [5]. Both 5-HPUA and DHU were found to be $\beta$-cytotoxic and more potent than alloxan. In agreement with previous observations [12] alloxan caused a triphasic blood glucose response. However, 5-HPUA or DHU elicited persistant hyperglycaemia after $30 \mathrm{~min}$ in overnight 
fasted animals, and the morphological changes, although similar in nature to those seen after alloxan, were more rapid in onset. The greater stability of DHU and 5-HPUA compared with alloxan may contribute towards their enhanced diabetogenic activity. Unexpectedly, more prolonged starving of the animals $(24 \mathrm{~h})$ delayed the hyperglycaemic response to DHU or 5-HPUA but not to alloxan: we have no explanation for this phenomenon.

The similarity between the acute actions of alloxan and DHU on islets of Langerhans in vitro [6] lends support to the belief that the mechanism of action is probably the same. Furthermore, DHU can be formed by reaction of alloxan with ammonium chloride [5] which may account for the hitherto unexplained potentiation of diabetogenic activity of alloxan by co-administration of ammonium salts [11].

The mechanism of diabetogenic action of alloxan has aroused considerable speculation [11]. Several points have been considered involving dominant features of alloxan chemistry: e. g. Strecker reaction, oxidation of sulphydryl compounds, and hydroxyl radical generation. Although it has become increasingly clear that oxidation-reduction processes play a central role in the diabetogenic action of alloxan, the identify of the primary reductant is unclear. Dimethylalloxan, however, which shares all these properties, is non-diabetogenic. This fact strongly suggests that certain additional properties must be involved to account for the diabetogenic effect. Perhaps the particular structure present in alloxan and its methylated analogues is sufficient to affect the insulin release mechanisms, but, in addition, a free pyrimidine nitrogen is needed for chronic cytotoxic effects. The structure-activity relationships in this series seem to point to a requirement for at least one free nitrogen within an intact pyrimidine ring and for three adjacent carbonyl groups or their hydrated equivalents [10]. Recent studies of alloxan-like compounds derived from uric acid have shown that the fragments from the five membered ring of uric acid may be present in the structure while retaining full or even enhanced diabetogenic potency [5].

A plausible hypothesis that $\beta$-cytotoxic metabolites may originate from uric acid has acquired much attention [reviews 7, 11, 12]. Whether or not alloxan-like compounds which selectively injure $\beta$ cells are true intermediates in the oxidative degradation of purines in vivo, they are chemically related to uric acid. Further studies of alloxan-like compounds derived from uric acid may shed some light on these ideas and should also help to clarify the mechanism of their action on the $\beta$ cell.

Acknowledgements. These studies were supported by the Croatian Republic Research Fund. We wish to acknowledge with thanks the skilful technical assistance of Mrs. B. Slijepcevic and B. Mandic throughout this study.

\section{References}

1. Poje M, Paulus EF, Rocic B (1980) Oxidation of uric acid. 1. Structural revision of uric acid glycols. J Org Chem 45: 65-68

2. Poje M, Rocic B (1979) A reinvestigation of alloxan-like compounds derived from uric acid. Tetrahedron Letters: 4781-4782

3. Poje M, Rocic B, Vickovic I, Bruvo M (1982) Propellane-type derivatives of uric acid. X-ray structure of 9-acetyl-4,5-(1-methoxyethylidenedioxy)-4, 5-dihydrouric acid. J Chem Soc Chem Commun: 1338

4. Poje M, Rocic B (1980) Diabetogenic action of alloxan-like derivatives of uric acid. Experientia 36: 78-79

5. Poje M, Rocic B, Sikirica M, Vickovic I, Bruvo M (1983) Oxidation of uric acid. 4. Synthesis, structure and diabetogenic action of 2,4,6 $(1 \mathrm{H}, 3 \mathrm{H})$-pyrimidinetrione-5-iminium salts and their alloxan-like covalent adducts. J Med Chem 26: 861-865

6. Tait SPC, Poje M, Rocic B, Ashcroft SJH (1983) Diabetogenic action of alloxan-like compounds: the effect of dehydrouramil hydrate hydrochloride on isolated islets of Langerhans of the rat. Diabetologia 25:360-364

7. Poje M, Rocic B, Skrabalo Z (1980) B-Cytotoxic action of alloxanlike compounds derived from uric acid. Diab Croat 9: 145-166

8. Huggett AStG, Nixon DA (1957) Enzymic determination of blood glucose. Biochem J 66: 12P

9. Kikui Y, Seguchi H, Mizoguti H (1977) A differential staining method for A- and B-cells in the pancreatic islets of Langerhans. Acta Histochem Cytochem 10:10-13

10. Bruckmann G, Wertheimer E (1947) Alloxan studies: the action of alloxan homologues and related compounds. J Biol Chem 168: 241-256

11. Cooperstein SJ, Watkins D (1981) Action of toxic drugs on islet cells. In: Cooperstein SJ, Watkins D (eds). The islets of Langerhans: biochemistry, physiology and pathology, Academic Press, New York, pp 387-425

12. Herman JB, Medalie JH, Goldbourt U (1976) Diabetes, prediabetes and uricaemia, Diabetologia 12: 47-52

Received: 7 November 1983

and in revised form: 2 July 1984

Dr. B. Rocic

Institute for Diabetes 'Vuk Vrhovac'

Medical Faculty

University of Zagreb

Krijesnice 66

YU-41000 Zagreb

Yugoslavia 